\title{
T-helper 1 cells induce alveolitis but do not lead to pulmonary fibrosis in mice
}

\author{
K. Irifune, A. Yokoyama, N. Kohno, K. Sakai, K. Hiwada
}

T-helper 1 cells induce alveolitis but do not lead to pulmonary fibrosis in mice. K. Irifune, A. Yokoyama, N. Kohno, K. Sakai, K. Hiwada. (C) ERS Journals Ltd 2003. ABSTRACT: T-helper (Th)1 cells have a pivotal role in the pathogenesis of hypersensitivity pneumonitis. Continued low-level exposure to the antigens may induce chronic hypersensitivity pneumonitis with lung fibrosis. Although such exposure may activate Th1 cells in the lung, it is not known whether activation of Th1 cells per se can lead to pulmonary fibrosis. To determine this, the lung pathology induced by Th1 clones was investigated.

Mice (BALB/c) were injected intraperitoneally with Th1 clones 1-4 times. Each injection was performed 4 days apart and was followed by repeated exposure to aerosolised ovalbumin (OVA) once a day for 5 days.

The number of macrophages and lymphocytes in bronchoalveolar lavage fluids (BALF) increased as the number of Th1 transfers increased. The number of neutrophils also increased but peaked in the second transfer and then decreased following further transfers. Increased cell infiltration, thickness of alveolar walls and number of type II cells in the lung occurred. However, histological findings showed no evidence of fibrosis and hydroxyproline levels did not increase. Findings of histology and BALF were ameliorated 2 weeks after the discontinuation of OVA exposure, indicating the reversibility of the Th1-induced pathology.

In conclusion, adoptive transfer of T-helper 1 cells results in reversible alveolitis but does not lead to pulmonary fibrosis.

Eur Respir J 2003; 21: 11-18.
The Second Dept of Internal Medicine, Ehime University School of Medicine, Onsen-gun, Ehime, Japan.

Correspondence: A. Yokoyama Second Dept of Internal Medicine Shigenobu

Onsen-gun

Ehime 791-0295

Japan

Fax: 81899605306

E-mail: yokoyan@m.ehime-u.ac.jp

Keywords: Cytokine

hypersensitivity pneumonitis

sarcoidosis

T-helper 1/T-helper 2

Received: October 312001

Accepted after revision: May 222002
Interstitial lung diseases consist of $>100$ individual diseases, with either known or unknown causes [1]. They occur as a primary disease or as part of systemic diseases, such as collagen-vascular diseases, and can sometimes lead to respiratory failure and death. This group of diseases share common features and clinical courses. Initial injury to epithelial cells is thought to be followed by alveolitis. The alveolitis is sometimes self-limiting, but may become progressive. In the latter case, lung fibrosis occurs. The mechanisms for these pathological changes are not fully understood. However, T-cells may have an important role in the pathophysiology of these diseases.

Among T-cells, CD4+ cells can be divided into two subsets based on their secretion pattern of cytokines. T-helper (Th) 1 cells characteristically secrete Interferon (IFN)- $\gamma$ and lymphotoxin. Th2 cells secrete interleukin (IL)-4, IL-5, and IL-13 [2]. Th1 cells can be identified in the lung of the interstitial lung diseases, such as chronic beryllium disease, pulmonary sarcoidosis, post-transplant bronchiolitis obliterans and Wegener's granulomatosis [3-6]. In addition, accumulating evidence suggests a pivotal role of Th1cell-mediated, delayed-type hypersensitivity in the pathogenesis of hypersensitivity pneumonitis (HP) [7]. HP is induced by inhalation of a wide variety of environmental domestic antigens and may occur in three clinical forms: acute, subacute or chronic type.
Continued low-level exposure to the aetiological antigens may induce subacute and chronic HP. Unrecognised and untreated subacute HP may progress to chronic HP, which is characterised by irreversible lung fibrosis. Although continued antigen exposure may activate Th1 cells in the lung, it is not known whether continuous activation of Th1 cells per se can lead to pulmonary fibrosis.

In this report, the effects of adoptively transferred ovalbumin (OVA)-specific Th1 clones was studied to understand Th1-induced lung pathology, specifically to determine whether chronic activation of Th1 cells can induce fibrotic changes in the lungs.

\section{Materials and methods}

\section{Characterisation of T-cell clones}

OVA (grade V; Sigma Chemical Co., St. Louis, MO, USA)-reactive Th1 clones were generated by injecting antigen $(500 \mu \mathrm{g}$ emulsified in Complete Freund's Adjuvant) subcutaneously into the tail and footpads of mice. Single cell suspensions were made from the draining popliteal and inguinal lymph nodes 5-7 days following injection. Clones were isolated by directly placing primed lymph node cells $\left(1\right.$ cell $\cdot$ well $\left.^{-1}\right)$, mitomycin C-treated splenocytes $\left(1 \times 10^{6} \cdot\right.$ well $\left.^{-1}\right)$, antigen 
$\left(100 \mathrm{mg} \cdot \mathrm{mL}^{-1}\right)$, and IL-2 $\left(50 \mathrm{U} \cdot \mathrm{mL}^{-1}\right)$ in 96-well flatbottom tissue culture plates containing Roswell Park Memorial Institute (RPMI) 1640 media supplemented with 10\% heat-inactivated foetal calf serum (Gibco, Grand Island, NY, USA), $100 \mathrm{U} \cdot \mathrm{mL}^{-1}$ penicillin $\mathrm{G}$, $100 \mu \mathrm{g} \cdot \mathrm{mL}^{-1}$ streptomycin, $50 \mathrm{mM}$ 2-mercaptoethanol (Sigma), and $10 \mathrm{mM} \mathrm{N-2-hydroxyethylpiperazine-}$ N - 2 - ethanesulphonic (HEPES) (Sigma). Cells in positive wells were expanded, selected for growth to antigen and recloned at 0.3 cells $\cdot$ well $^{-1}$. Clones used for the present study were maintained for at least 10 months. The media of $\mathrm{T}$-cell clones cultured in stimulation with concanavalin A $\left(1 \mu \mathrm{g} \cdot \mathrm{mL}^{-1}\right.$; Vector Labs, Burlingame, CA, USA) were collected after $48 \mathrm{~h}$ and stored at $-80^{\circ} \mathrm{C}$ until use. The concentrations of IFN- $\gamma$, IL-4, and IL-5 in the media of T-cell clones were measured with comercially available enzymelinked immunosorbent assay (ELISA) kits (Endogen, Boston, MA, USA) according to the manufacturer's instructions. For proliferation assay, these clones were seeded $\left(2 \times 10^{5} \cdot \mathrm{mL}^{-1}\right)$ in 96-well flat-bottomed plates in the presence or absence of OVA $\left(1 \mathrm{mg} \cdot \mathrm{mL}^{-1}\right)$, an anti-IL-2 monoclonal antibody (mAb) (S4B6), and an anti-IL-4 mAb (11B11) [8]. The clones were cultured at $37^{\circ} \mathrm{C}$ in a carbon dioxide $\left(\mathrm{CO}_{2}\right)$ incubator for $72 \mathrm{~h}$. ${ }^{3} \mathrm{H}$-thymidine $\left(0.5 \mu \mathrm{Ci} \cdot\right.$ well $\left.^{-1}\right)$ was added $15 \mathrm{~h}$ before harvest, and incorporation of ${ }^{3} \mathrm{H}$-thymidine was measured with a liquid scintillation counter.

\section{Adoptive transfer of T-helper 1 clones}

Mice (BALB/c, 6-8 week-old females; Charles River Laboratories, Kanagawa, Japan) were injected intraperitoneally with Th1 clones $\left(5 \times 10^{6} \cdot 500 \mu \mathrm{L}^{-1}\right.$ phosphate buffer saline (PBS) per mouse) or PBS alone, followed by repeated challenges with aerosolised OVA $\left(50 \mathrm{mg} \cdot \mathrm{mL}^{-1}, 20 \mathrm{~min}\right)$ for 5 or 10 days (fig. 1a). Challenge was performed in a $50 \mathrm{~mL}$ plastic tube, OVA aerosol was delivered with a DeVilbiss 646 nebuliser (DeVilbiss Corp., Somerset, PA, USA) driven by compressed air at $5 \mathrm{~L} \cdot \mathrm{mL}^{-1}$, as previously described with some modifications $[9,10]$.

The protocol for serial transfer of Th1 clones is shown in figure $1 \mathrm{~b}$. Mice were injected intraperitoneally with the same number of Th1 clones $\left(5 \times 10^{6}\right)$ up to 4 times and each injection (4 days apart) was followed by repeated exposures to aerosolised OVA $\left(50 \mathrm{mg} \cdot \mathrm{mL}^{-1}\right.$, $20 \mathrm{~min}$ ) for 5 days. Therefore, four transfers involved exposure to OVA every day for 20 days.

Mice were killed by cervical dislocation under anaesthesia $24 \mathrm{~h}$ after the final exposure to OVA. Bronchoalveolar lavage fluid (BALF) $(0.5 \mathrm{~mL}$, three times) was obtained from the whole lungs by cannulating the surgically exposed trachea. Cells in the BALF were counted with a haemocytometer. The differential cell count was obtained using cytospin preparations (May-Giemsa staining). For histological examination, the lungs were removed and fixed with $4 \%$ paraformaldehyde. Then the tissues were embedded in paraffin and cut into $5 \mu \mathrm{m}$ sections. The sections were stained with haematoxylin and eosin and elasticaMasson's trichrome.
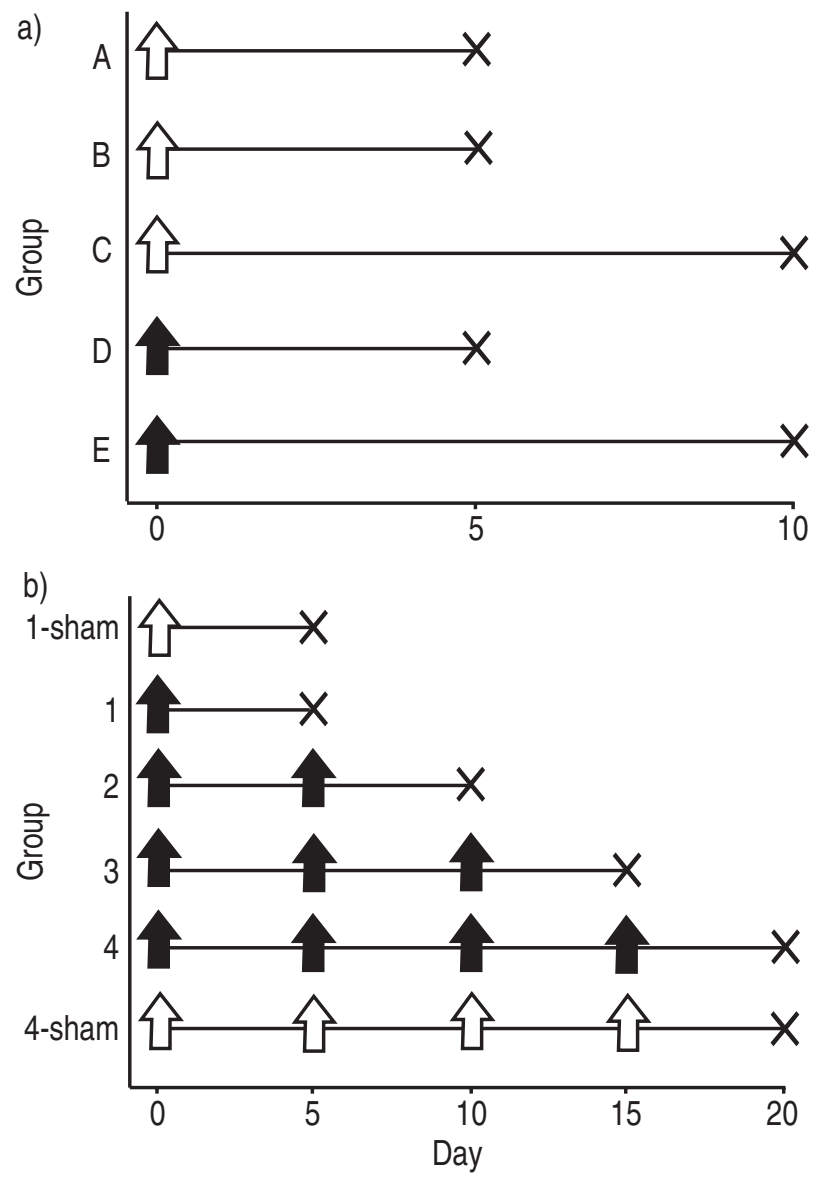

Fig. 1. - Schema of protocols for the experimental mice. a). Mice were injected intraperitoneally with T-helper 1 clones $\left(5 \times 10^{6}\right.$; groups D and E; filled arrow) or phosphate buffered saline (PBS) alone (groups A, B, and C; open arrow), followed by repeated challenges to aerosolised ovalbumin (OVA) for 5 (groups B and D) or 10 days (groups $\mathrm{C}$ and $\mathrm{E}$ ), or with PBS for 5 days (group A). b) Mice were repeatedly injected intraperitoneally with the same number of Th1 clones $\left(5 \times 10^{6}\right)$ or PBS alone (1-sham and 4-sham) up to four times, and each injection (4 days apart) was followed by repeated exposures to aerosolised OVA $\left(50 \mathrm{mg} \cdot \mathrm{mL}^{-1}\right.$, $20 \mathrm{~min}$ ) for 5 days. Mice were examined $24 \mathrm{~h}$ after the final exposure to OVA.

\section{Determinations of specific antibody levels}

OVA-specific immunogolobulin (Ig)E and $\operatorname{IgG} 2 \mathrm{a}$ serum antibody titres were determined with indirect ELISA [9, 10]. Plates (Costar, Cambridge, MA, USA) were coated with $200 \mu \mathrm{g} \cdot \mathrm{mL}^{-1}$ of OVA diluted in $0.1 \mathrm{M} \mathrm{NaHCO}_{3}$ (pH 8.3). Following overnight incubation at $4{ }^{\circ} \mathrm{C}$, the plates were washed and blocked with $1 \%$ bovine serum albumin (Sigma) for $2 \mathrm{~h}$ at $37^{\circ} \mathrm{C}$. Serially diluted serum samples were applied to the blocked wells and incubated overnight at $4{ }^{\circ} \mathrm{C}$. Horseradish peroxidase-conjugated rat antimouse IgE and IgG2a mAbs (Pharmingen, San Diego, CA, USA) diluted in 50\% goat serum (Gibco, Grand Island, NY, USA) were added to the plates, which were then incubated for $2 \mathrm{~h}$ at $37^{\circ} \mathrm{C}$. After washing three times, wells were developed using OPDA solution $(0.3 \%$ $o$-phenylenediamine dihydrochloride, $0.02 \% \quad \mathrm{H}_{2} \mathrm{O}_{2}$, $0.15 \mathrm{M}$ citrate buffer, $\mathrm{pH} 4.9$ ), and the absorbance at $492-620 \mathrm{~nm}$ was determined with a microplate 
autoreader. As an internal standard, pooled serum from OVA-immunised BALB/c mice was included in each assay. The standard serum was assigned a value of $100 \mathrm{U} \cdot \mathrm{mL}^{-1}$ for both OVA-specific IgE and IgG2a.

\section{Count of type II pneumocytes}

For analysis of type II cells, the lungs were fixed in 3\% glutaraldehyde in $0.1 \mathrm{M}$ phosphate buffer $(\mathrm{pH} 7.3)$ at $4{ }^{\circ} \mathrm{C}$ and post-fixed in $2 \% \mathrm{OsO}_{4}$ in aqueous solution for $2 \mathrm{~h}$ at $4^{\circ} \mathrm{C}$. The specimens were stored en bloc in $2 \%$ uranyl acetate overnight at $4^{\circ} \mathrm{C}$ and embedded in Epon 812 after dehydration. Semithin $0.5 \mu \mathrm{m}$ sections were cut with a diamond knife, mounted on glass slides, stained with toluidine blue, and observed with light microscopy. Then the sections were ion-etched in an ion coater (IB-5; Eiko, Ibaragi, Japan) at $300 \mathrm{~V}$ at $0.03 \mathrm{kPa}$ $(\mathrm{mmHg})$ for $60 \mathrm{~min}$. Following platinum coating, the sections were observed at $20 \mathrm{kV}$ with scanning electron microscopy (S-800; Hitachi, Tokyo, Japan). Alveolar type II cells were distinguished by identifying the characteristic lamellar body. Type II cells in the alveolar area were counted at $\times 1000$ magnification in at least 10 areas per specimen. Data are presented as number of type II cells $\cdot \mathrm{mm}^{-2}$.

\section{Measurement of hydroxyproline}

To estimate the total amount of collagen as an index of pulmonary fibrosis, the hydroxyproline content of the left lung was measured in each group according to a previously described method [11]. After wet weights were measured, the homogenised left lungs were hydrolysed, and the hydroxyproline contents of the hydrolysates were analysed using high-performance liquid chromatography. Data are expressed as $\mathrm{mg} \cdot \mathrm{g}^{-1}$ wet lung tissue.

\section{Reversibility of the pathological changes}

To evaluate the reversibility of alveolitis, mice that underwent four Th1 cell transfers were observed for an additional 2 weeks after final exposure to OVA without further treatment. They were then killed, and BALF analysis and histological examination were performed.

\section{Statistical analysis}

Data are expressed as the mean \pm SD unless otherwise stated. Variables were analysed with the MannWhitney U-test for comparison of two variables.

\section{Results}

\section{Characterisation of $T$-cell clones}

The pattern of cytokines produced by T-cell clones is shown in table 1. D2, S1 and S4 produced large
Table 1.-Cytokine production by T-cell clones

\begin{tabular}{lccc}
\hline Clone $^{\#}$ & \multicolumn{3}{c}{ Cytokine production $\mathrm{pg} \cdot \mathrm{mL}^{-1}$} \\
\cline { 2 - 4 } & IFN- $\gamma$ & IL-4 & IL-5 \\
\hline D2 & 4237 & $<5$ & $<5$ \\
S1 & 4340 & $<5$ & 13 \\
S4 & 4424 & $<5$ & $<5$ \\
\hline
\end{tabular}

\#: T-helper 1 cell clones $\left(1 \times 10^{6} \cdot\right.$ well $\left.^{-1}\right)$ were cultured with a ConA $\left(5 \mu \mathrm{g} \cdot \mathrm{mL}^{-1}\right)$ for $48 \mathrm{~h}$.

amounts of IFN- $\gamma$ and little or no amount of IL-4 and IL-5. These clones proliferated in response to OVA antigen and their proliferation was inhibited by antiIL-2 but not by anti-IL-4 mAb (data not shown). These results indicate that these clones belong to the Th1 subset.

\section{Effects of single adoptive transfer of T-helper 1 clones}

As shown in table 2 , mice with a single intraperitoneal injection of Th1 cells followed by repeated exposure to aerosolised OVA for 5 days (group D) or 10 days (group E) showed a significantly greater increase of cells in BALF than the increase in the PBSprimed, PBS-challenge control mice (group A). The rate of increase was 3-fold and 5-fold greater than that of the controls for 5-day (group B) and 10-day (group C)-challenge, respectively. The increased cells were macrophages, neutrophils, and lymphocytes (table 2). However, only limited cell infiltration was observed in the lungs (fig. 2a). Control mice exposed to OVA for 5 days (group B) or 10 days (group C) without Th1 injection showed no significant changes compared with PBS-primed, PBS-challenged mice (group A). Essentially equivalent results were obtained in the other Th1 clones, S1 and S4. Transfers of Th1 cells followed by exposure to OVA induced neither antigen-specific $\operatorname{IgG} 2 \mathrm{a}$ nor $\operatorname{IgE}$ responses in the present condition (data not shown).

\section{Effects of serial adoptive transfers of T-helper 1 clones}

As shown above, a single transfer of Th1 cells induced a limited inflammation in the lungs. Therefore, the effects of chronic activation of Th1 cells in the lung were explored by increasing the number of transfers.

Total cells in BALF increased in correlation with the increase of Th1 cell transfers (fig. 3). Mice with four transfers showed $\sim 3$ times more cells in BALF than the mice with a single transfer. The increase of the cell types in BALF was not uniform. The increase of neutrophils peaked in the second transfer $(19.7 \pm$ $\left.3.1 \times 10^{3} \cdot \mathrm{mL}^{-1}\right)$ and decreased thereafter. In contrast, macrophages and lymphocytes increased in correlation with the increased number of Th1-cell transfers. Repeated transfers of Th1 cells induced a strong antigen-specific IgG2a but not IgE antibody response (fig. 4), indicating that transferred Th1 cells are active 
Table 2. - Total cell number and cell differentials in bronchoalveolar lavage fluid

\begin{tabular}{|c|c|c|c|c|c|c|c|}
\hline \multirow[t]{2}{*}{ Group $^{\#}$} & \multirow[t]{2}{*}{ Priming } & \multirow{2}{*}{$\begin{array}{l}\text { Exposure } \\
\text { to OVA } \\
\text { (days) }\end{array}$} & \multirow{2}{*}{$\begin{array}{l}\text { Total cell } \\
\text { number } \\
\times 10^{5} \cdot \mathrm{mL}^{-1}\end{array}$} & \multicolumn{4}{|c|}{$\begin{array}{c}\text { Differentials } \% \\
\left(\text { Cell number } \times 10^{3} \cdot \mathrm{mL}^{-1}\right)\end{array}$} \\
\hline & & & & Macrophage & Lymphocytes & Neutrophil & Eosinophils \\
\hline A & PBS & $(5 ; \mathrm{PBS})$ & $0.5 \pm 0.1$ & $\begin{array}{c}98.6 \pm 0.9 \\
(40.1 \pm 7.5)\end{array}$ & $\begin{array}{c}0.5 \pm 0.3 \\
(0.4 \pm 0.4)\end{array}$ & $\begin{array}{c}0.8 \pm 0.7 \\
(0.4 \pm 0.3)\end{array}$ & $\begin{array}{c}0.0 \pm 0.0 \\
(0.0 \pm 0.0)\end{array}$ \\
\hline B & PBS & 5 & $0.6 \pm 0.1$ & $\begin{array}{c}98.8 \pm 0.4 \\
(56.1 \pm 7.3)\end{array}$ & $\begin{array}{l}1.1 \pm 0.3 \\
(0.6 \pm 0.2)\end{array}$ & $\begin{array}{c}0.2 \pm 0.2 \\
(0.1 \pm 0.1)\end{array}$ & $\begin{array}{c}0.0 \pm 0.0 \\
(0.0 \pm 0.0)\end{array}$ \\
\hline $\mathrm{C}$ & PBS & 10 & $0.6 \pm 0.2$ & $\begin{array}{l}98.9 \pm 0.4 \\
(58.2 \pm 15.7)\end{array}$ & $\begin{array}{l}1.0 \pm 0.4 \\
(0.6 \pm 0.3)\end{array}$ & $\begin{array}{c}0.0 \pm 0.0 \\
(0.0 \pm 0.0)^{*}\end{array}$ & $\begin{array}{c}0.0 \pm 0.0 \\
(0.0 \pm 0.0)\end{array}$ \\
\hline $\mathrm{D}$ & D2 & 5 & $1.8 \pm 0.3^{*}$ & $\begin{array}{c}74.3 \pm 3.5^{* *} \\
(136.2 \pm 20.6)^{* *}\end{array}$ & $\begin{array}{l}18.0 \pm 1.8^{* *} \\
(33.0 \pm 5.8)^{* *}\end{array}$ & $\begin{array}{c}7.4 \pm 3.1^{* *} \\
(13.6 \pm 6.8)^{* *}\end{array}$ & $\begin{array}{l}0.6 \pm 0.5^{*} \\
(1.0 \pm 0.9)^{*}\end{array}$ \\
\hline E & D2 & 10 & $3.1 \pm 0.2^{*}$ & $\begin{array}{c}73.4 \pm 3.7 * * \\
(226.6 \pm 10.5)^{* *}\end{array}$ & $\begin{array}{l}19.9 \pm 5.5^{* *} \\
(62.3 \pm 20.2)^{* *}\end{array}$ & $\begin{array}{c}6.3 \pm 2.3^{* *} \\
(19.5 \pm 6.8)\end{array}$ & $\begin{array}{c}0.3 \pm 0.3 \\
(1.1 \pm 0.9)\end{array}$ \\
\hline
\end{tabular}

Data are presented as mean \pm SD. OVA: ovalbumin; PBS: phosphate buffer saline. *: $\mathrm{p}<0.05$; and **: $\mathrm{p}<0.01$ compared with (Group A); ${ }^{\#}: \mathrm{n}=6$.
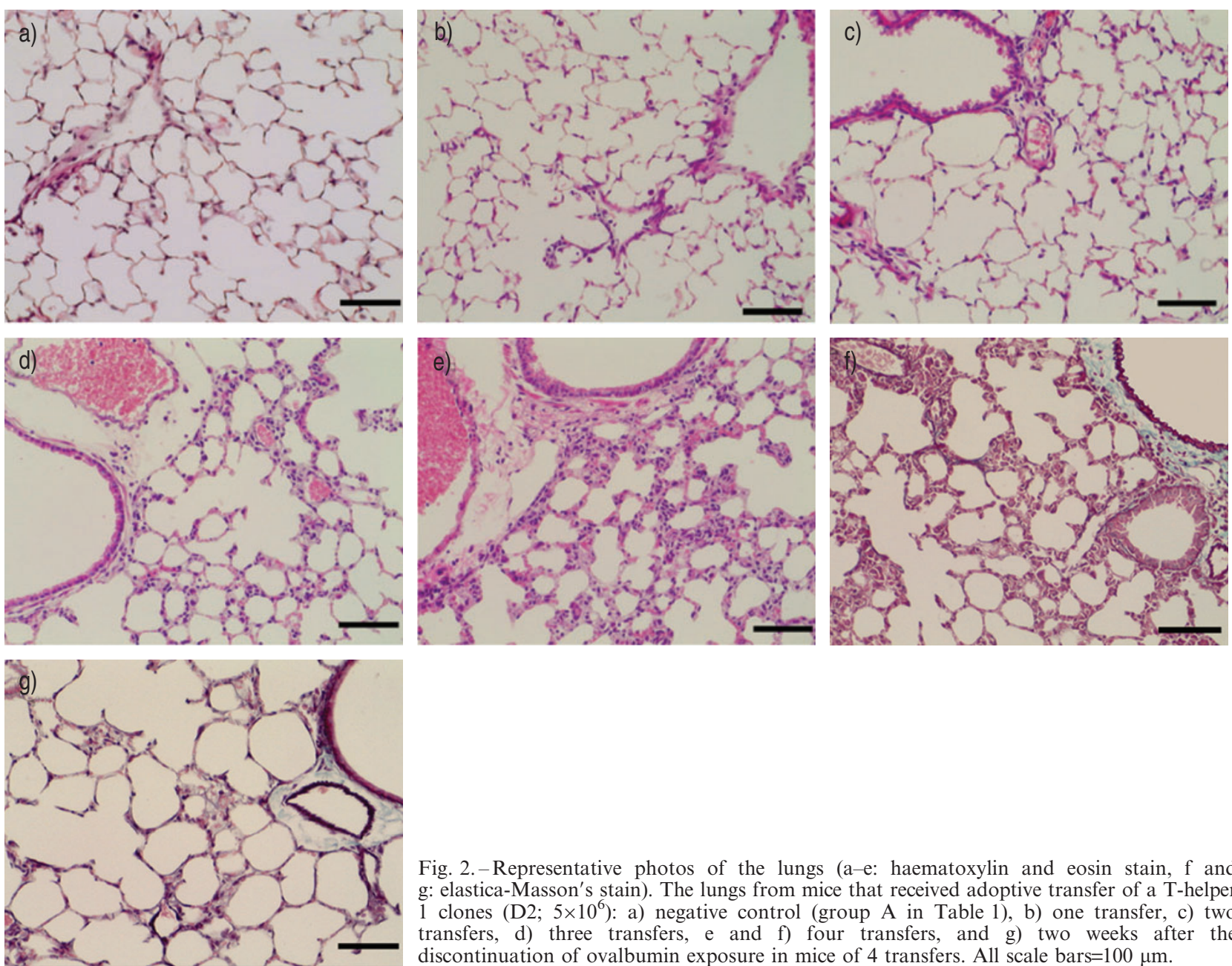

Fig. 2.- Representative photos of the lungs (a-e: haematoxylin and eosin stain, $\mathrm{f}$ and g: elastica-Masson's stain). The lungs from mice that received adoptive transfer of a T-helper 1 clones (D2; $5 \times 10^{6}$ ): a) negative control (group A in Table 1), b) one transfer, c) two transfers, d) three transfers, e and f) four transfers, and g) two weeks after the discontinuation of ovalbumin exposure in mice of 4 transfers. All scale bars $=100 \mu \mathrm{m}$.

in vivo. Th1 cells facilitate production of $\operatorname{IgG} 2$ a subclass, whereas Th2 favours IgG1 and IgE antibodies [12].

Histologically, more prominent cellular infiltration in the lung was observed as number of Th1 transfers increased (fig. 2b-e). Massive infiltration of mononuclear cells and a marked thickening of alveolar walls were observed in mice with four Th1 transfers (fig. 2e). Data for the Th1 clone, D2, are shown, and essentially equivalent results were obtained in the other Th1 clones, S1 and S4. 


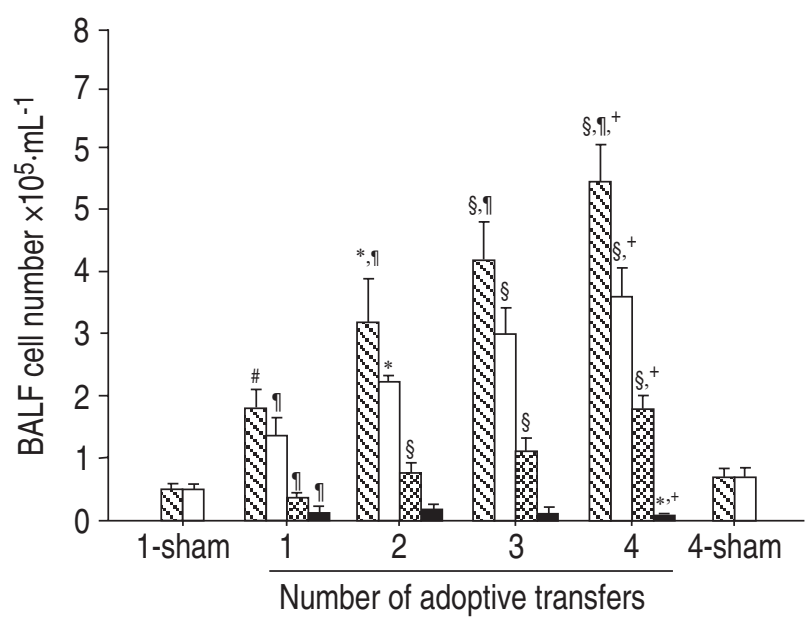

Fig. 3. - Total cell number $(\mathbb{\nabla})$ and cell differentials ( $\square$ : macrophages; $\mathbf{E}$ : lymphocytes; $\mathbf{0}$ : neutrophils) bronchoalveolar lavage fluid (BALF) from mice adoptively transferred with a Th1 clone (D2) 1-4 times followed by repeated exposure to ovalbumin aerosols. Data are presented as total cell number $\cdot \mathrm{mL}^{-1}($ mean $\pm \mathrm{SD})$ $(\mathrm{n}=6$ for each group). Cell differentials are shown as the mean values for each. *: $\mathrm{p}<0.05$ and $\S: \mathrm{p}<0.01$ versus 1 transfer. \#: $\mathrm{p}<0.05$ and ${ }^{\top}: \mathrm{p}<0.01$ versus 1 -sham; ${ }^{+}: \mathrm{p}<0.01$ versus. 4 -sham.

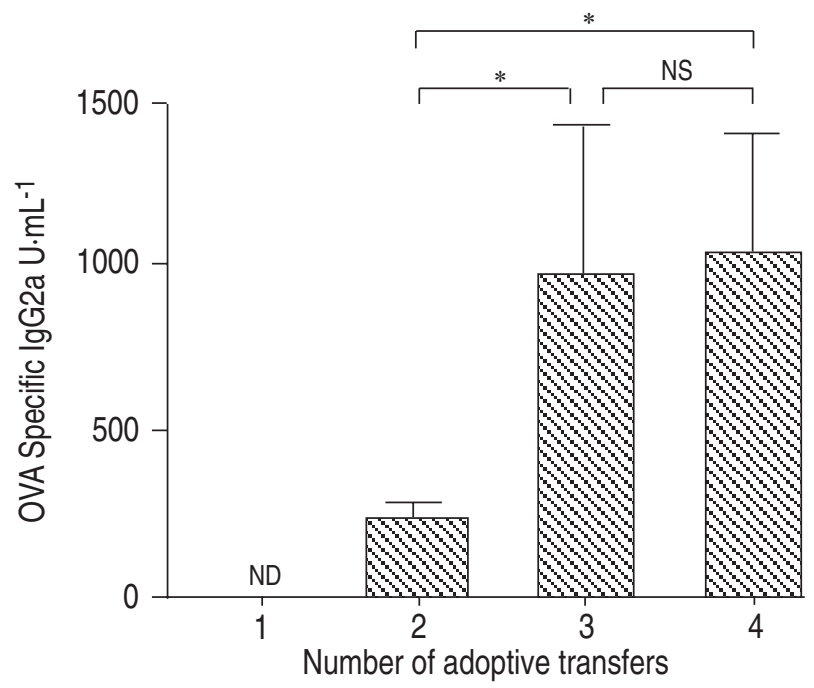

Fig. 4. - Serum concentrations of ovalbumin (OVA)-specific immunoglobulin (Ig)G2a. The titres for OVA-specific serum IgG2a antibody were determined by indirect enzyme linked immunosorbent assay. OVA-specific IgE was not detected in any groups. Data are presented as mean \pm SD. ND: not detectable; NS: nonsignificant. *: $\mathrm{p}<0.01$ between the groups.

Effects of T-helper 1 transfers on the number of type II pneumocytes and lung fibrogenesis

Regeneration of type II epithelial cells are the hallmark of epithelial damage in interstitial lung diseases. In microscopic examination, type II cells seemed to be prominent in mice with more than two Th1 transfers. Therefore, type II alveolar epithelial cells were counted using electron microscopy. As shown in figure 5, the number of type II cells significantly

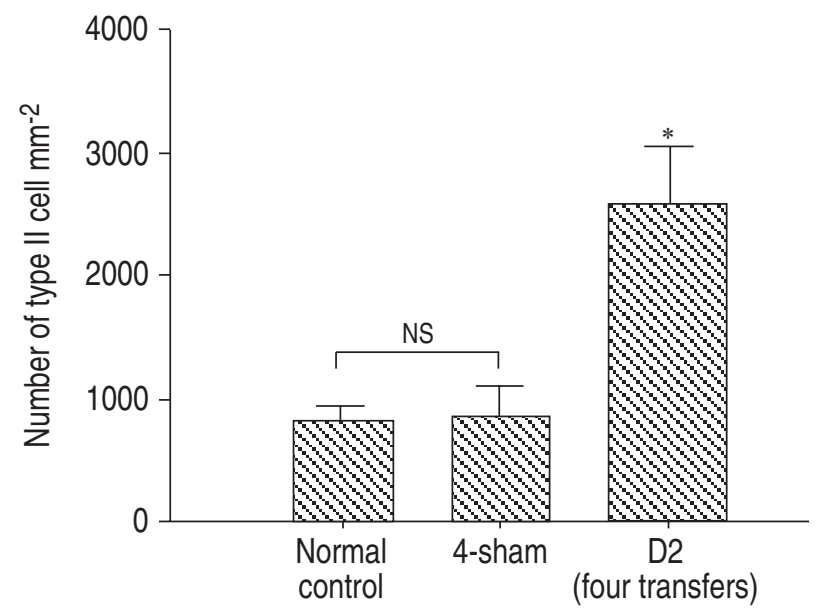

Fig. 5. - Number of type II cells. Type II cells were counted in 10 fields at $1000 \times$ magnification with an electron microscope. Data are presented as mean \pm SD per $\mathrm{mm}^{2}$ ( $\mathrm{n}=6$ for each).NS: nonsignificant. *: $\mathrm{p}<0.01$ versus normal control or 4 -sham group.

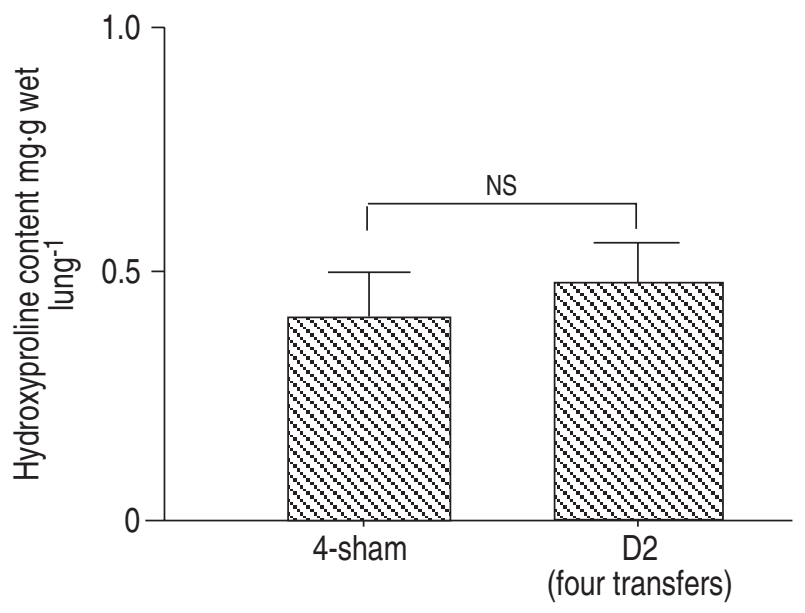

Fig. 6.-Hydroxyproline content in the lungs. The hydroxyproline content of the left lung was measured with high performance liquid chromatography. Data are presented as mean \pm SD in each group $(n=6)$.

increased in mice with four transfers in comparison with normal mice or control mice exposed to OVA alone.

As shown in figure 2e, even the lungs of mice with four Th1 transfers appeared to have no fibrosis. To confirm this point, lung fibrogenesis was assessed by elastica-Masson's staining and hydroxyproline content. Elastica-Masson's staining disclosed no collagen deposits in the lungs (fig. $2 \mathrm{f}$ ), and the hydroxyproline content did not increase (fig. 6).

\section{Reversibility of the pathological changes}

To evaluate the reversibility of the alveolitis, mice with four Th1 cell transfers were killed 2 weeks after the final exposure to OVA. BALF cell numbers were significantly decreased (total cells $1.5 \pm 0.3 \times 10^{5}$, macrophages $87.7 \pm 5.8 \%$, lymphocytes $12 \pm 5.7 \%$, neutrophils 
$0.4 \pm 0.5 \%$, eosinophils $0 \%$, basophils $0 \%$; $=6$ ). Furthermore, pathological features of alveolitis, such as infiltration of cells and thickness of alveolar wall, were ameliorated in these mice (fig. $2 \mathrm{~g}$ ).

\section{Discussion}

The present study demonstrated that repeated transfers of antigen-reactive Th1 clones followed by exposure to aerosolised antigen could induce interstitial pneumonitis in mice. The interstitial pneumonitis is characterised by infiltration of mononuclear cells, thickened alveolar walls without fibrosis and reversibility of these changes. These pathological changes resemble human interstitial lung diseases such as hypersensitivity pneumonitis and sarcoidosis. However, the pathological hallmarks of the diseases are granulomatous interstitial pneumonitis. Since no granulomas were observed in the present model, it should be noted that the lung pathology induced by Th1 cells alone was obviously different from these human lung diseases.

Recently, experimental models induced by adoptively transferring antigen-specific Th1 or Th2 cells once into naive mice followed by repeated inhalations corresponding antigens, were evaluated [13-19]. Adoptive transfer of $\mathrm{Th} 2$ clones or polarised $\mathrm{Th} 2$ population from $\mathrm{T}$-cell receptor-transgenic (TCR-Tg) mice resulted in airway hyperresponsiveness and a prominent perivascular and peribronchial infiltration by eosinophils and mononuclear cells [13-16]. These features induced by Th2 cells resemble human bronchial asthma. Conversely, adoptive transfer of Th1 cells from TCR-Tg mice was reported to induce the same degree of cell infiltration as Th2 cells around bronchovascular bundles with mononuclear cells and neutrophils but only few eosinophils [15-16, 18]. Even in the short-term transfer model described by RANDOLPH et al. [19] single OVA challenge after infusion of OVA-specific TCR-Tg Th1 population resulted in marked airway but not alveolar inflammation. Alveolitis had not been observed in these reports. Furthermore, a marked neutrophilia (20-50\% of total cells) was observed in the bronchial lavage of Th1-transferred mice [15-17], although this finding was not always observed [18]. Similar to Th1 cells from TCR-Tg mice, single infusion of a Th1-dominant cell population obtained from splenocytes of mouse models of HP induced by repeated inoculations of antigen was reported to induce the prominent HP-like pathology [20].

In the present study, single administration of Th1 cells lead to only faint changes. Additional transfers were necessary to develop characteristic alveolitis. Although neutrophils were increased in BALF, it was very small increase even in the second transfer $(<3 \%)$ when the increase peaked. These points are different from reports mentioned above. The reason for the differences between the present model and previous reports is unclear at present. Intravenous administration of Th1 clones followed by exposure to OVA resulted in a little more lymphocytes in BALF, but essentially the same in histological findings (unpublished observation). Therefore, the route of administration may not be a factor for the differences. In previous reports, the polarised population induced by cytokines and anticytokine antibodies was used after a short culture time. Therefore the population may be Th1 dominant, but many cells in the population may still have characteristics of the Th0. More importantly, the characteristics of such polarised cells may lose or exchange the characteristics in vivo. These characteristics of the Th1 population used in the previous studies may possibly contribute to the differences between previous and present results.

Th1-induced alveolitis was not accompanied by fibrosis, as evidenced by elastica-Masson's staining and no increase of hydroxyproline content. Therefore, the authors concluded that activated Th1 cells alone could not lead to fibrotic changes in the present model. It should be noted that genetic background may influence this point. $\mathrm{BALB} / \mathrm{c}$ is a poor responder strain to bleomycin [21]. However, $\mathrm{BALB} / \mathrm{c}$ is also susceptible to lung fibrosis induced by silica particles, asbestos and radiation [22-24]. Although alveolitis precedes fibrosis, additional cytokines may be needed for fibrogenesis. IL-1, tumour necrosis factor- $\alpha$ and transforming growth factor (TGF)- $\beta$ are important mediators of fibrosis [25-27]. IL-4 can stimulate collagen synthesis from fibroblasts, whereas IFN- $\gamma$ is a potent inhibitor for synthesis [28]. In this context, the relationships between a predominance of Th1 or Th2 cytokines and the reversibility of interstitial pneumonitis are interesting [29, 30]. Th1-dominant hypersensitivity pneumonitis is usually a reversible disease, whereas idiopathic pulmonary fibrosis, which always results in irreversible pulmonary fibrosis, is known as a Th2 predominant disease $[31,32]$. In this sense, adoptive transfer of Th2 clones alone or together with Th1 clones would be interesting to disclose their roles in pulmonary fibrosis. Furthermore, it should be mentioned that the role of CD8+ T-cells would be important in human HP, since the CD8+ population is usually greater than CD4+ T-cell subset in the BALF and parenchyma. The CD8+ T-cell population could also be functionally divided into two subsets, $\mathrm{Tc} 1$ and Tc2, based on the cytokine secretion pattern [33]. Recent reports disclosed that they may contribute to tumour rejection, protection against viral infection, and pathological changes in chronic obstructive pulmonary diseases [34, 35]. Although clinical investigation of Tc1 and Tc2 on alveolitis is quite limited at present, adoptive transfer experiments using Tc1 or Tc2 clones would also gain important insights into the pathophysiology of interstitial lung diseases.

It was found that the alveolitis induced by Th1 cell activation in the lung was accompanied by an increase in type II epithelial cells. Proliferation of type II cells occurred after almost all types of diffuse lung injury. Preferential denudation of type I epithelial cells is a common initial feature of experimental models of interstitial pneumonitis, such as bleomycin, radiation, paraquat and silica. Within several days, dedifferentiation and replication of type II cells occur as these cells spread out to replace the damaged type I cells. Exposure to aerosolised OVA would not cause any apparent injury in control mice. Therefore, Th1 cells 
may injure syngeneic epithelial cells. Another explanation for the increase in type II cells is their preferential growth. Even if such growth occurs, it may not be a direct effect of Th1 cytokines. Although some growth factors for Type II cells are known such as epidermal growth factor, hepatocyte growth factor, TGF- $\alpha$ and acidic and basic fibroblast growth factor [36-37], Th1 cytokines have not been demonstrated to induce growth.

In conclusion, the presence of activated T-helper 1 cells in the lungs induces alveolitis. This alveolitis cannot lead to fibrosis and is reversible. The factors leading from alveolitis to pulmonary fibrosis remain to be determined.

Acknowledgements. The authors would like to thank K. Kondo and H. Katayama for their assistance in the course of this study.

\section{References}

1. Schwarz MI. Approach to the understanding, diagnosis, management of interstitial lung diseases. In: Schwarz MI, King TE, eds. Interstitial Lung Disease. 3rd Edn. Hamilton, B.C. Decker Inc., 1998; pp. 1-30.

2. Abbas AK, Murphy KM, Sher A. Functional diversity of helper T lymphocytes. Nature 1996; 383: 787-793

3. Lombardi G, Germain C, Uren J, et al. HLA-DP allele-specific $\mathrm{T}$ cell responses to beryllium account for DP-associated susceptibility to chronic beryllium disease. J Immunol 2001; 166: 3549-3555.

4. Moller DR, Forman JD, Liu MC, et al. Enhanced expression of IL-12 associated with Th1 cytokine profiles in active pulmonary sarcoidosis. $J$ Immunol 1996; 156: 4952-4960.

5. Boehler A, Bai XH, Liu M, et al. Upregulation of T-helper 1 cytokines and chemokine expression in post-transplant airway obliteration. Am J Respir Crit Care Med 1999; 159: 1910-1917.

6. Lúdvíksson BR, Sneller MC, Chua KS, et al. Active Wegener's granulomatosis is associated with HLA$\mathrm{DR}^{+} \mathrm{CD} 4^{+} \mathrm{T}$ cells exhibiting an unbalanced Th1-type T cell cytokine pattern: reversal with IL-10. J Immunol 1998; 160: 3602-3609.

7. Patel AM, Ryu JH, Reed CE. Hypersensitivity pneumonitis: Current concepts and future questions. J Allergy Clin Immunol 2001; 108: 661-670.

8. Yokoyama A, Evavold B, Dunn DE, Quintans J. Production of IL-2 and IFN by $\mathrm{T}_{\mathrm{H}} 2$ clones. Immunol Lett 1989; 21: 119-126.

9. Sakai K, Yokoyama A, Kohno N, Hiwada K. Effect of different sensitizing doses of antigen in a murine model of atopic asthma. Clin Exp Immunol 1999; 118: 9-15.

10. Zhao G-D, Yokoyama A, Kohno N, Sakai K, Hamada H, Hiwada K. Effect of suplatast tosilate (IPD-1151T) on a mouse model of asthma: Inhibition of eosinophilic inflammation and bronchial hyperresponsiveness. Int Arch Allergy Immunol 2000; 121: 116-122.

11. Edwards CA, O'Brien WD Jr. Modified assay for determination of hydroxyproline in a tissue hydrolyzate. Clin Chim Acta 1980; 104: 161-167.
12. Stevens TL, Bossie A, Sanders VM, et al. Regulation of antibody isotype secretion by subsets of antigenspecific helper T cells. Nature 1988; 334: 255-258.

13. Kaminuma O, Mori A, Ogawa K, et al. Successful transfer of late phase eosinophil infiltration in the lung by infusion of helper T cell clones. Am J Respir Cell Mol Biol 1997; 16: 448-454.

14. Li X-M, Schofield BH, Wang Q-F, Kim K-H, Huang S-K. Induction of pulmonary allergic responses by antigen-specific Th2 cells. J Immunol 1998; 160: $1378-1384$.

15. Cohn L, Homer RJ, Marinov A, Rankin J, Bottomly K. Induction of airway mucus production by $\mathrm{T}$ helper 2 (Th2) cells: a critical role for interleukin 4 in cell recruitment but not mucus production. J Exp Med 1997; 186: 1737-1747.

16. Li L, Xia Y, Nguyen A, Feng L, Lo D. Th2-induced eotaxin expression and eosinophilia coexist with Th1 responses at the effector stage of lung inflammation. J Immunol 1998; 161: 3128-3135.

17. Cohn L, Tepper JS, Bottomly K. Cutting edge: IL4-independent induction of airway hyperresponsiveness by Th2, but not Th1, cells. J Immunol 1998; 161: 3813-3816

18. Hansen G, Berry G, DeKruyff RH, Umetsu DT. Allergen-specific Th1 cells fail to counterbalance Th2 cell-induced airway hyperreactivity but cause sever airway inflammation. J Clin Invest 1999; 103: 175-183.

19. Randolph DA, Stephens R, Carruthers CJL, Chaplin DD. Cooperation between Th1 and Th2 cells in a murine model of eosinophilic airway inflammation. J Clin Invest 1999; 104: 1021-1029.

20. Schuyler M, Gott K, Cherne A, Edwards B. Th1 $\mathrm{CD} 4^{+}$cells adoptively transfer experimental hypersensitivity pneumonitis. Cell Immunol 1997; 177: 169-175.

21. Helene M, Lake-Bullock V, Zhu J, Hao H, Cohen DA, Kaplan AM. T cell independence of bleomycininduced pulmonary fibrosis. J Leukoc Biol 1999; 65: 187-195.

22. Corsini E, Luster Ml, Mahler J, Craig WA, Blazka ME, Rosenthal GJ. A protective role for T lymphocytes in asbestos-induced pulmonary inflammation and collagen deposition. Am J Respir Cell Mol Biol 1994; 11: 531-539.

23. Suzuki N, Ohta K, Horiuchi T, et al. T lymphocytes and silica-induced pulmonary inflammation and fibrosis in mice. Thorax 1996; 51: 1036-1042.

24. Sharplin J, Franko AJ. A quantitative histological study of strain-dependent differences in the effects of irradiation on mouse lung during the intermediate and late phases. Radiat Res 1989; 119: 15-31.

25. Kasahara K, Kobayashi K, Shikama Y, et al. The role of monokines in granuloma formation in mice: the ability of interleukin 1 and tumor necrosis factor- $\alpha$ to induce lung granulomas. Clin Immunol Immunopathol 1989; 51: 419-425.

26. Raghow R, Irish P, Kang AH. Coordinate regulation of transforming growth factor $\beta$ gene expression and cell proliferation in hamster lungs undergoing bleomycin-induced pulmonary fibrosis. $J$ Clin Invest 1989; 84: 1836-1842.

27. Piguet PF, Collart MA, Grau GE, Sappino AP, Vassalli P. Requirement of tumour necrosis factor for development of silica induced pulmonary fibrosis. Nature 1990; 344: 245-247.

28. Serpier H, Gillery P, Salmon-Ehr V, et al. Antagonistic effects of interferon- $\gamma$ and interleukin-4 on 
fibroblast cultures. J Invest Dermatol 1997; 109: 158 162.

29. Lukacs NW, Hogaboam C, Chensue SW, Blease K, Kunkel SL. Type 1/type 2 cytokine paradigm and the progression of pulmonary fibrosis. Chest 2001; 120: Suppl. 1, 5S-8S.

30. Sime PJ, O'Reilly KM. Fibrosis of the lung and other tissues: new concepts in pathogenesis and treatment. Clin Immunol 2001; 99: 308-319.

31. Wallace WAH, Ramage EA, Lamb D, Howie SEM. A type 2 (Th2-like) pattern of immune response predominates in the pulmonary interstitium of patients with cryptogenic fibrosing alveolitis (CFA). Clin Exp Immunol 1995; 101: 436-441.

32. Gross TJ, Hunninghake GW. Idiopathic pulmonary fibrosis. N Engl J Med. 2001; 345: 517-525.

33. Mosmann TR, Li L, Sad S. Functions of CD8 T-cell subsets secreting different cytokine patterns. Semin Immunol. 1997; 9: 87-92.

34. Kemeny DM. CD8+ T cells in atopic disease. Curr Opin Immunol 1998; 10: 628-633.

35. Kemeny DM, Vyas B, Vukmanovic-Stejic M, et al. CD8(+) T cell subsets and chronic obstructive pulmonary disease. Am J Respir Crit Care Med 1999; 160: S33-37.

36. Leslie CC, McCormick-Shannon K, Mason RJ. Heparin-binding growth factors stimulate DNA synthesis in rat alveolar type II cells. Am J Respir Cell Mol Biol 1990; 2: 99-106.

37. Shiratori M, Michalopoulos G, Shinozuka H, Singh G, Ogasawara H, Katyal SL. Hepatocyte growth factor stimulates DNA synthesis in alveolar epithelial type II cells in vitro. Am J Respir Cell Mol Biol 1995; 12: 171180. 